indicated the pressing need for adequate space, equipment and instructors, and led to a number of definite recommendations for the development of a co-ordinated programme for leisure time in C.C.C. camps.

\section{The Radio and Culture}

AT the recent annual meeting of the Institut de France, Dr. Georges Duhamel, the well-known writer and editor of the Mercure de France, deplored what he called the constitutional defects of the radio, which he declared has an unfavourable and even demoralizing effect on the intellectual habits of the middle classes. In the first place he asserted that the radio draws many persons away from reading by depriving them of part of their leisure and making them gradually lose the habit of active cerebral work. Some people, he continued, are misled by the radio into imagining that the mind can attend to two objects at the same time, which is a mistake. Far from contributing to true culture, the radio encourages a taste for superficial ideas which are easily acquired and soon lost. In answer to the objection that the radio adds to without supplanting the other modes of information and knowledge, Dr. Duhamel maintained that we cannot safely disregard or decry a system of culture which has been tested for centuries in favour of a new process of which the remote results are necessarily quite unknown. As regards the plea that the radio is a source of pleasure, Dr. Duhamel retorted that no pleasure can last several hours a day, and that for some people the radio ceases almost at once to be a pleasure and becomes a craving.

\section{London School of Hygiene and Tropical Medicine}

THE report for 1937-38 of the London School of Hygiene and Tropical Medicine by the dean, Prof. W. Jameson, recently issued, surveys the administrative changes and the teaching and research work of the School during the year. In the Departments of Bacteriology and Epidemiology studies have been in progress for eighteen months on the effect of diet on the fertility, survival and growth of mice, and their resistance to infection, which show that a diet containing a proportion of animal protein, compared with one containing vegetable protein only, renders individual mice more resistant to infection of Bact. typhimurium, and significantly reduces the mortality in herds in which the disease is spreading by natural contact. In the Department of Entomology much work has been done on the biology of mosquitoes, the bed bug, lice and other parasites, and an important investigation continued on the spread of mineral oils on water in relation to anti-malarial work by destruction of mosquito larvæ. In the Department of Bacteriology studies have been continued upon the isolation of the antigenic components from various bacteria, and their value as immunizing agents. The physiological problems of air raids precautions, in particular gasproof clothing, helminthic parasites of domestic animals, and problems connected with the root eelworm disease of potatoes, are a few of the other subjects that are under investigation. The Ross
Institute of Tropical Hygiene reports upon its antimalarial work in various Colonies, Yugoslavia and South America.

\section{Malaria in Albania}

IN an inaugural thesis (Thèse de Paris, No. 548; 1938), F. L. Richards states that malaria is the most prevalent disease in Albania, especially in the low-lying regions. where it is closely associated with the presence of lakes, marshes and other places inundated by the mountain water courses. It is more or less endemic in villages near streams and their affluents. Most of the patients under treatment in the hospitals are suffering from this complaint, which in some parts of the country affects 50 per cent of the population. All clinical forms of the disease are found, malignant tertian being the commonest. In addition to its high incidence in the civilian population, malaria is the most frequent disease in the Albanian army. Its prevalence is highest in June, July, August and September, and sometimes there is a rapid rise in the number of cases in October; but August and September are the months in which the disease is most intense. The death-rate is higher in children than in adults. The spread of the disease is favoured by the unhygienic habits of the Albanian people and is therefore most pronounced among the poor. At the suggestion of the King of Albania, a five-year plan has recently been introduced for combating the disease.

\section{Microscopy for the Chemist}

A Recent article by Prof. Alois Herzog (Zeiss Nach., 2, Hefte 5 and 6, 1938) is based upon the value of the microscope to the chemist for qualitative analytical determinations with minimal amounts of material. A number of simple methods is described involving the use of sublimation, distillation, precipitation, drying, crystallization, spot reactions, and other procedures with or without the addition of specified reagents, whereby crystals and other deposits having characteristic microscopical appearances are obtained, which serve to identify various metals and metallic and other salts, etc. Screens (sieves), animal and vegetable fibres, and miscellaneous inorganic substances like asbestos, and the use of the polarizing microscope are also briefly described. The article is illustrated with 97 excellent photomicrographs of the appearances obtained in the reactions, and full details are given as to how the objects were photographed, namely the camera, objective and ocular used, the illumination and the time of exposure.

\section{Physics in Crime Detection}

The Physics Forum of the November issue of the Review of Scientific Instruments is devoted to an account of the use made of physics in the detection of crime in the United States. It is written by J. Edgar Hoover, of the Federal Bureau of Investigation of the Department of Justice. Although the author refers to the use of radio in rapidly communicating information, the account is mainly con- 
cerned with optical methods : the microscope for the identification of hair, shreds of clothing or other small particles, for the examination of minute markings on bullets so as to identify the weapon used, or the markings on a cut window bar to identify the bolt cutter used, and, with the addition of polarizing prisms, the identification of soil stains on shoes or clothing. The spectroscope is used for identification of stains of all kinds, ultra-violet light for the identification of materials by their fluorescence, for the detection of erasures in documents or for reading documents written in secret ink invisible in ordinary light. X-rays are used for the examination of suspected parcels without opening them, and infra-red light for reading obliterated writing or printing on paper and other materials.

\section{Manganese Ores}

IN view of the great importance of manganese ores in modern steel manufacture, much interest is attached to a small book by Dr. A. W. Groves on "Manganese" (Second Edition. Imperial Institute, 1938. 3s. 6d. net). It is one of the series of monographs on mineral production. Ores occur in many lands, but large-scale production is confined to the Soviet Union, India, the Gold Coast, the Union of South Africa, Brazil, Egypt and Cuba. It is noteworthy that with the exception of the Soviet Union and to a small extent the United States, all great steelproducing countries have to rely upon imports from distant lands for their supplies of manganese. These ores are thus one of the most essential constituents of ocean trade. The book gives details of occurrence and production in all lands where the ore has been found and ends with a long bibliography.

\section{The Night Sky in January}

ThE moon is full on January 5, and new on January 20. Lunar conjunctions with the planets occur as follows: on January 14 with Mars; on January 16 with Venus; on January 23 with Jupiter and with Saturn on January 26. Mercury, Venus and Mars are morning stars. Mercury is at greatest western elongation $\left(23^{\circ}\right)$ on January 3 , and Venus reaches greatest western elongation $\left(47^{\circ}\right)$ on January 30. Venus rising shortly before $4 \frac{1}{2}$ U.T. is pre-eminently the bright and morning star. Jupiter, southing in the early afternoon, is conspicuous in the evening sky. Saturn is due south shortly after $18^{\mathrm{h}}$ on January 1 . The bright stars of the constellation of Orion and its associated constellations are passing the southern meridian about $22^{\mathrm{h}}$ in midJanuary. The Quadrantids radiating from Draco may be looked for about January 2. On January 1, an occultation of the planet Uranus (mag. 6.0) takes place; at Greenwich the disappearance occurs at $17^{\mathrm{h}} 0 \cdot 1^{\mathrm{m}}$ at position angle $51^{\circ}$ from the north point of the moon's image. On January 26, $\delta$ Piscium $\left(4 \cdot 6^{\mathrm{m}}\right)$ is occulted at $17^{\mathrm{h}} 1 \cdot 2^{\mathrm{m}}$, and on January 30 , $\varepsilon$ Tauri $\left(3 \cdot 6^{\mathrm{m}}\right)$ at $19^{\mathrm{h}} 39 \cdot 2^{\mathrm{m}}$, the respective position angles at disappearance being $12^{\circ}$ and $83^{\circ}$ from the north point.

\section{Announcements}

Prof. Erwin Schrödinger has been appointed by the Fondation Francqui as a visiting professor for the next six months to a "Chaire Francqui" in the University of Ghent, Belgium. His address is : Laboratory of Physics, Plateaustraat 22, Gand, Belgium.

M. EDMOND RoTHÉ, director of the Institute for the Physics of the Earth, University of Strasbourg, has been elected a correspondant for the Section of Astronomy of the Paris Academy of Sciences in succession to the late Prof. P. Stroobant.

Dr. Errol Ivor White has been appointed deputy keeper in the Department of Geology of the British Museum (Natural History) with effect from December 21, and Mr. Frederick Allan Bannister has been appointed deputy keeper in the Department of Mineralogy with effect from December 31. Dr. White entered the Museum as an assistant in 1922. He took the degree of D.Sc. in 1935, and throughout his service at the Museum has specialized on the fossil fishes, upon which he is a recognized authority. Mr. Bannister entered the Museum in 1927 as an assistant keeper and has specialized in the analysis of mineral structure by means of X-rays, in the development of which method he has taken a leading part.

THE annual meeting of the Mathematical Association will be held in King's College, Strand, London, W.C.2, on January 2-3 under the presidency of Mr. W. Hope-Jones. The subject of Mr. Hope-Jones's address will be "Simplicity and Truthfulness in Arithmetic". Discussions on the teaching of applied mathematics in technical colleges, and on the second report on the teaching of geometry have been arranged, and papers by Prof. W. L. Bragg on the symmetry of patterns and by Lord Stamp on education and statistical method in business have been promised. Further information can be obtained from Mr. G. L. Parsons, Peckwater, Eastcote Road, Pinner, Middlesex.

The Government of Cuba has decided to devote a million dollars to the campaign against tuberculosis.

A Ceremony in commemoration of the biologist and physician Lazzaro Spallanzani (1729-1799) will be held at Padua next spring at the same time as the International Congress of Experimental Biology, which will be under the patronage of the Italian Academy.

The Alvarenga do Piauhy (Brazil) Prize for 1939, which is worth about 200 dollars, will be awarded by the College of Physicians of Philadelphia in July next for the best memorial or the best unpublished essay on any branch of medicine. Recent publications brought to the attention of the committee before May I, 1939, will receive attention. Further information can be had from the Committee for the Alvarenga Prize, 19 South Twenty-second Street, Philadelphia, U.S.A. 